Pamiętnik Literacki 2014, 4, s. 195-211
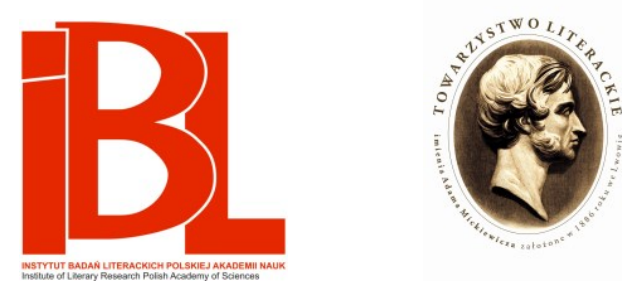

Recepcja poezji Wisławy Szymborskiej w Korei Południowej

Choi Sung Eun (Estera Czoj) 
CHOI SUNG EUN (ESTERA CZOJ) Hankuk University of Foreign Studies, Seoul

\section{RECEPCJA POEZJI WISŁAWY SZYMBORSKIEJ W KOREI POŁUDNIOWEJ*}

Twórczość Wisławy Szymborskiej po raz pierwszy została zaprezentowana w Korei dopiero po przyznaniu poetce literackiej Nagrody Nobla w 1996 roku. Wcześniej jej nazwisko było zupełnie obce czytelnikom koreańskim. Wraz z upływem czasu poezja Szymborskiej stawała się coraz bliższa Koreańczykom - do tego stopnia, że odbiła się echem nie tylko w kręgach związanych z literaturą czy, szerzej, z kulturą, ale także w całym społeczeństwie koreańskim.

Bezpośrednimi powodami zainteresowania się Koreańczyków poezją Szymborskiej były trzy doniosłe wydarzenia: po pierwsze, zdobycie przez poetkę Nagrody Nobla; po drugie, wydanie antologii poezji Szymborskiej w wersji koreańskiej: Kkeut-kwa sijak ${ }^{1}$ (긑과 시작 〈Koniec i poczatek〉) w 2007 roku; po trzecie, śmierć poetki w 2012 roku.

W niniejszej rozprawie chciałabym przedstawić koreański kontekst społeczno-kulturalny, jaki kreował różnorodne aspekty recepcji poezji Szymborskiej - w trzech okresach, których cezury czasowe wyznaczają trzy wspomniane tu wydarzenia.

\section{Pierwszy okres: od roku 1996 do roku 2006}

W roku 1996, kiedy poetce przyznano literacką Nagrodę Nobla, wiele osób w Korei chciało wiedzieć, kim jest Wisława Szymborska oraz jakie utwory napisała. Jedynym wtedy polonistą w całej Korei Południowej był Cheong Byung Kwon ${ }^{2}$. Warto wspomnieć, że w tamtym okresie nie było żadnego południowokoreańskiego naukowca, który doktoryzowałby się w Polsce. Przyczynę tego stanowił długotrwały (sięgający czasów koreańskiej wojny domowej) brak oficjalnych stosunków dyplomatycznych między Polską a Koreą Południowa.

* $\quad$ Praca napisana dzięki pomocy Hankuk University of Foreign Studies Research Fund of 2014/15 (This work was supported by Hankuk University of Foreign Studies Research Fund of 2014/15).

$1 \quad$ Wszystkie tytuły książek, artykułów i wierszy, a także nazwy czasopism i dzienników oraz nazwy własne instytucji zapisane w koreańskim alfabecie hangeul podaję w zmodyfikowanym systemie latynizacji z 2000 roku (system zmodyfikowany przez Ministerstwo Kultury i Turystyki w Korei Południowej). Odstępstwem od tej reguły są imiona i nazwiska autorów tekstów czy nazwy niektórych czasopism oficjalnie już funkcjonujące w obiegu naukowym i w prasie w trochę innym zapisie. 
Pomimo takiego - powiedzieć by można: fatalnego - stanu rzeczy zaczęto przy różnych okazjach drukować pojedyncze utwory Szymborskiej w licznych dziennikach oraz czasopismach literackich, takich jak: „Simunhak [Poezja]”, „Munhak Sasang [Przegląd Literacki]”, „Hyeondae Munhak [Literatura Współczesna]”. Cheong Byung Kwon, który był wówczas kierownikiem polonistyki na Hankuk University of Foreign Studies ${ }^{3}$, opublikował 10 artykułów na temat twórczości Szymborskiej. Pisali o niej także: slawista Choi Gun Young ${ }^{4}-4$ artykuły, oraz anglista Yoo Young i poeta będacy wtedy na emigracji w Stanach Zjednoczonych Lee Pung Ho - po jednym artykule. Ponadto Cheong Hyeon Jong, który był znanym poetą i eseistą, a jednocześnie koreanista, przetłumaczył $\mathrm{z}$ angielskiego 5 wierszy Szymborskiej. Niemal wszystkie ukazujące się wówczas artykuły miały charakter wyłącznie krótkich zarysów, zawierających ogólne informacje zwłaszcza o życiu poetki. Wśród nich znalazła się tylko jedna naukowa praca autorstwa Cheong Byung Kwona, zatytułowana Swimboreuseuka-ui si-e natanan ingan-kwa sanghwang (Egzystencja ludzka w twórczości Wisławy Szymborskiej) ${ }^{5}$.

Innym problemem był fakt, że zapis nazwiska poetki nie został w języku koreańskim ujednolicony. Zapisywano je alfabetem hangeul, więc na różne sposoby:

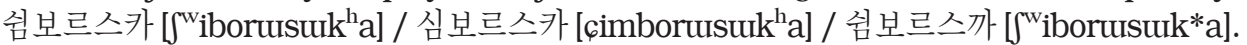
Podobnie imię miało kilka postaci graficznych: 비스와바 [bisuwaba] / 비슬라바 [bisulaba] / 비수라바 [bisuraba] ${ }^{6}$.

Oto wiersze Szymborskiej, które zostały przetłumaczone i opublikowane w Korei w roku 1996:

\begin{tabular}{|c|c|c|c|}
\hline & Tłumacz & Nazwa czasopisma & Wiersze \\
\hline 1 & \multirow{3}{*}{$\begin{array}{l}\text { Cheong Byung } \\
\text { Kwon } \\
\text { (HUFS); polonista }\end{array}$} & $\begin{array}{l}\text { „Yeonhap Nyuseu” / } \\
\text { „Yonhap News" } \\
\text { 1996, nr z } 3 \text { X }\end{array}$ & Krótkie życie naszych przodków \\
\hline 2 & & $\begin{array}{c}\text { „Hyeondae Sihak } \\
\text { [Poezja Współczesna]” } \\
\text { 1996, nr z listopada }\end{array}$ & $\begin{array}{l}\text { Nic dwa razy, Szukam słowa, } \\
\text { Pisanie życiorysu, } \\
\text { Krótkie życie naszych przodków }\end{array}$ \\
\hline 3 & & $\begin{array}{c}\text { „Woekuk Munhak Yeongu” / } \\
\text { „Foreign Literature Studies” } \\
\text { nr } 2 \text { (1996) }\end{array}$ & $\begin{array}{c}\text { Z Korei, Wietnam, Dzieci epoki, } \\
\text { Uśmiechy, Utopia, } \\
\text { Widok z ziarnkiem piasku }\end{array}$ \\
\hline 4 & $\begin{array}{l}\text { Choi Gun Young } \\
\text { (Yonsei Univer- } \\
\text { sity); slawista }\end{array}$ & $\begin{array}{l}\text { dziennik „Chosun Ilbo” } \\
\text { 1996, nr z października }\end{array}$ & Sól, Wielka liczba \\
\hline 5 & $\begin{array}{l}\text { Yoo Young } \\
\text { (Yonsei Univer- } \\
\text { sity); anglista }\end{array}$ & $\begin{array}{l}\text { „Simunhak [Poezja]” } \\
\text { nr } 304 \text { (1996, listopad) }\end{array}$ & $\begin{array}{l}\text { Muzeum, Eksperyment, Uśmiechy, } \\
\text { Pisanie życiorysu, Widziane z góry }\end{array}$ \\
\hline
\end{tabular}

3 Dalej wzmiankując o tym uniwersytecie stosuję skrót HUFS.

4 Choi Gun Young jest rusycystą, a jednocześnie studiował polonistykę jako drugi kierunek.

$5 \quad$ W tym artykule Cheong określił trzy główne tendencje ujawniające się, jego zdaniem, w twórczości Szymborskiej. Są to: głęboka refleksja nad niepowtarzalnością czasu, dystans wobec podmiotu lirycznego oraz przezwyciężanie antropocentryzmu.

6 W języku koreańskim nie ma spółgłoski, która brzmi tak samo jak polskie „w”. 


\begin{tabular}{|c|c|c|c|}
\hline 6 & $\begin{array}{c}\text { Lee Pung Ho; } \\
\text { poeta na emigracji } \\
\text { w Stanach Zjedno- } \\
\text { czonych }\end{array}$ & $\begin{array}{c}\text { „Simunhak [Poezja]” } \\
\text { n } 305 \text { (1996, grudzień) }\end{array}$ & $\begin{array}{c}\text { Miłość szczéśliwa, Wieczór autorski, } \\
\text { Pochwała snów, Niebo }\end{array}$ \\
\hline 7 & $\begin{array}{c}\text { Cheong Hyeon } \\
\text { Jong; } \\
\text { poeta, koreanista }\end{array}$ & $\begin{array}{c}\text { "Hyeondae Munhak } \\
\text { [Literatura Współczesna]” } \\
\text { nr 503 (1996, listopad) }\end{array}$ & $\begin{array}{c}\text { Muzeum, Pisanie życiorysu, } \\
\text { Jarmark cudów, Widziane } z \text { góry, } \\
\text { Cebula }\end{array}$ \\
\hline
\end{tabular}

Cheong Byung Kwon i Choi Gun Young przetłumaczyli wiersze wprost z języka polskiego, natomiast pozostali tłumacze przekładali $-\mathrm{z}$ konieczności $-\mathrm{z}$ języka angielskiego. Wiadomo, że tzw. translacje pośrednie zazwyczaj mają znacznie ograniczoną możliwość oddania sensu tekstu pierwotnego.

Podkreślenia godny wydaje się fakt, że w tym okresie ukazał się w czasopiśmie „Munhak Sasang [Przegląd Literacki]”, tłumaczony na koreański, artykuł polskiego uczonego i krytyka literackiego, profesora Michała Głowińskiego Niepowtarzalna oryginalność - o poezji Wisławy Szymborskiej („Nowe Książki” z listopada 1996). W tym czasopiśmie również zamieszczony został przekład na koreański wywiadu z Szymborska, którego udzieliła poetka polskiemu tygodnikowi „Polityka” (z 12 XI 1996) ${ }^{7}$. Tłumaczem obu tekstów był Choi Gun Young. W mojej ocenie artykuł Głowińskiego, jak i wywiad z poetką dawały koreańskiemu czytelnikowi zdecydowanie dużo więcej sposobności do zapoznania się ze światem twórczości Szymborskiej aniżeli niektóre wcześniejsze koreańskie artykuły zawierające tylko ogólne informacje o życiu poetki.

10 II 1997 ukazał się w Korei pierwszy zbiór poezji Szymborskiej Morae algaenki-ga inneun punggyeong (Widok $z$ ziarnkiem piasku). W tomie obok 66 wierszy znalazło się również przemówienie Szymborskiej w dniu przyznania Nagrody Nobla. Tłumaczka tomiku, koreanistka Lee Hae Kyung, pracowała wówczas jako wykładowczyni w Katedrze Japonistyki i Koreanistyki Uniwersytetu Warszawskiego ${ }^{8}$. Przekład tego zbioru jest, niestety, pod wieloma względami nieudany, wykazuje np. pewne błędy strukturalno-semantyczne. Ta edycja zaspokoiła jedynie częściowo ciekawość koreańskich czytelników, a zainteresowanie poezją Szymborskiej osłabło.

W roku 1999 Choi Gun Young, slawista, napisał artykuł 20segi pollandeu munhak-kwa nobel munhaksang (Literatura polska XX wieku i literacka Nagroda Nobla) ${ }^{9}$, w którym próbował analizować, dlaczego akurat Szymborska otrzymała Nagrodę Nobla, a nie Herbert czy Różewicz. Co ciekawe, autor przedstawił nawet kilka utworów Szymborskiej z wczesnych lat pięćdziesiątych, czyli z okresu poetyki socrealistycznej, starając się w ten sposób wykazać szczególne znaczenie jej twórczości w polskim społeczeństwie XX wieku.

W roku 2000 została przełożona i wydana w Korei książka Nobelsang-eul badeun

$7 \quad$ Wywiad przeprowadziła dziennikarka G. Łęcka.

8 Lee Hae Kyung mieszkała w Warszawie i uczestniczyła w lektoracie języka polskiego, ale nie była specjalistką od literatury polskiej.

9 Artykuł ukazał się w wydawanym przez Hankuk Seullabeu Hakheo (Koreańskie Stowarzyszenie Studiów Slawistycznych) piśmie „Seullabeu Hakbo” / „Slavic Studies” (1999, nr 1). 
yeoseongdeul (Laureatki Nagrody Nobla) autorstwa niemieckiej pisarki Charlotte Kerner ${ }^{10}$. Przedstawiono w niej życie i osiagnięcia 13 laureatek Nagrody Nobla, m.in. Wisławy Szymborskiej, Marii Skłodowskiej-Curie, Toni Morrison, Matki Teresy z Kalkuty, Nadine Gordimer. Dzięki tej książce przynajmniej część Koreańczyków zwróciła uwagę na nazwisko Szymborskiej.

W roku 2003 w kinach koreańskich wyświetlano wyprodukowany w Hongkongu film Turn Left, Turn Right, w którym wykorzystano, w formie motta, cytat z utworu Szymborskiej Miłość od pierwszego wejrzenia. Dzięki wielkiej popularności tego obrazu również wiersz chwilowo wzbudził zainteresowanie koreańskich entuzjastów filmu, zwłaszcza młodzieży.

W ciagu kolejnych lat nazwisko Szymborskiej pojawiało się w prasie koreańskiej jedynie raz w roku, w październiku, przy okazji przyznawania kolejnej literackiej Nagrody Nobla - wśród nazwisk jej innych laureatów. Niestety, nigdy nie wspominano o konkretnych wierszach poetki.

Początki badań naukowych nad twórczością Szymborskiej przypadają na okres po roku 2000, kiedy to absolwenci koreańskiej polonistyki HUFS zaczęli wracać z Polski po odbytych tam studiach, zakończonych tytułem magisterskim lub doktorskim.

Od roku 2004 do 2006 w Korei ukazały się 4 artykuły naukowe na temat poezji Szymborskiej, których jestem autorką.

\begin{tabular}{|c|c|c|c|c|}
\hline & Tytuł koreański & Tytuł polski & Czasopismo & Rok \\
\hline 1 & $\begin{array}{c}\text { Biseuwaba Swimboreuseuka-ui } \\
\text { si-e natanan ingan-ui siljonjeok } \\
\text { jakak yeongu: sidaebyeol } \\
\text { daepyojak-e daehan bunseok-eul } \\
\text { tonghayeo }\end{array}$ & $\begin{array}{c}\text { Egzystencjalne postrzeganie } \\
\text { człowieka w poezji Wisławy } \\
\text { Szymborskiej przez pryzmat } \\
\text { analizy reprezentatywnych } \\
\text { utworów autorki }\end{array}$ & $\begin{array}{c}\text { „Dongyureop Yeongu” / } \\
\text { „East European } \\
\text { Studies” t. 13, nr } 1\end{array}$ & 2004 \\
\hline 2 & $\begin{array}{c}\text { Biseuwaba Swimboreuseuka-ui } \\
\text { si-e natanan samul-ui bonjir-eul } \\
\text { hyanghan siman yeongu }\end{array}$ & $\begin{array}{c}\text { „Oko natury” - ku esencji } \\
\text { podmiotu pojawiajacego się } \\
\text { w poezji Szymborskiej }\end{array}$ & $\begin{array}{l}\text { „Segye Munhak Bigyo } \\
\text { Yeongu” / „Comparative } \\
\text { Study of World } \\
\text { Literature” nr } 12\end{array}$ & 2005 \\
\hline 3 & $\begin{array}{c}\text { Biseuwaba Swimboreuseuka- } \\
\text {-wa No Jang sasang-ui } \\
\text { sangsaengjeok·yugironjeok } \\
\text { jayeongwan }\end{array}$ & $\begin{array}{c}\text { Ekologiczny i organiczny } \\
\text { światopoglad } w \text { poezji } \\
\text { Szymborskiej i } w \text { filozofii } \\
\text { Lao-Zhuanga }\end{array}$ & $\begin{array}{c}\text { „Dongseo Bigyo } \\
\text { Munhak Jeoneol” / } \\
\text { „The Journal of } \\
\text { East-West Comparative } \\
\text { Literature” nr } 12\end{array}$ & 2005 \\
\hline 4 & $\begin{array}{c}\text { Biseuwaba Swimboreuseuka-ui } \\
\text { si-wa No Jang sasang-e natanan } \\
\text { mu-reul tonghan jonjae-ui insik } \\
\text { yeongu }\end{array}$ & $\begin{array}{c}\text { Nicość jako geneza istnienia } \\
\text { w poezji Szymborskiej } \\
i w \text { idei Lao-Zhuanga }\end{array}$ & $\begin{array}{c}\text { „Segye Munhak Bigyo } \\
\text { Yeongu” / „Comparative } \\
\text { Study of World } \\
\text { Literature” nr } 14\end{array}$ & 2006 \\
\hline
\end{tabular}

W tym okresie również udostępniłam koreańskiemu czytelnikowi w kilku czasopismach literackich ponad 20 wierszy Szymborskiej w moim własnym przekładzie. Jako Koreanka i polonistka jestem zawsze zainteresowana badaniami porównaw-

10 Ch. Ke rne r, Nobelsang-eul badeun yeoseongdeul (Laureatki Nagrody Nobla). Przeł. Ki m Y o u ng He e. Seul 2000. 
czymi nad literaturą Wschodu i Zachodu, zwłaszcza odkrywaniem pewnych paraleli między literatura polska a literaturą Dalekiego Wschodu. W związku z tym próbowałam w kilku artykułach przeprowadzić analizę niektórych wątków, np. wątku „nicości” i „niebytu” w poezji Szymborskiej przy wykorzystaniu idei Lao-Zhuanga, ważnej i reprezentatywnej filozofii Dalekiego Wschodu ${ }^{11}$.

\section{Drugi okres: od roku 2007 do roku 2011}

Poezja Szymborskiej, która była poza zasięgiem zainteresowania czytelników koreańskich przez dość długi czas, ponownie znalazła się w centrum uwagi od momentu, kiedy ukazała się koreańska edycja wyboru jej wierszy w moim przekładzie, zatytułowana Kkeut-kwa sijak (Koniec i poczatek), czyli od 2 VII 2007. Opublikowało ją wydawnictwo „Munji” - jedno z największych i najlepszych w całej Korei.

Po studiach w Polsce myślałam stale o przetłumaczeniu wierszy Szymborskiej na język koreański, ale trudno było znaleźć odpowiednie wydawnictwo. Co więcej, upłynęło już sporo czasu od przyznania poetce Nagrody Nobla. Nie było też znaczących wydarzeń, które mogłyby pobudzić zainteresowanie twórczością Szymborskiej wśród Koreańczyków. Ostatecznie zgłosiłam projekt do „Daesan Segye Munhak Beonyeok Jiwon Peurogeuraem”, czyli do „Programu Wsparcia Tłumaczenia Literatury Światowej”, którego patronem jest prywatna Fundacja Daesan. Program powstał w 1999 roku w celu wzbogacania literatury koreańskiej poprzez przekłady i interpretację literatury obcej. Osoba zgłaszająca powinna sama wybrać utwór do tłumaczenia oraz przedstawić na piśmie argumenty dowodzące znaczenia i wartości tego utworu, a ponadto załączyć 30 stronic tłumaczenia jako przykład. Fundacja przyznaje grant osobie przez nią wybranej, który zwiększa szansę na wydanie tłumaczonego dzieła w renomowanym wydawnictwie „Munji” oraz wprowadza dany utwór na liste „Serii Światowej Literatury Pięknej Daesan” ${ }^{12}$.

W grudniu 2002 uzyskałam środki $z$ tego programu na przekład poezji Szymborskiej i rozpoczęłam nad nim intensywne prace. Pod koniec 2004 roku ukończyłam tłumaczenie 205 wierszy, pochodzących $\mathrm{z}$ dwóch tomików - Wiersze wybrane (2002) i Chwila (2002). Musiałam jednak długo czekać na wydanie, ponieważ było kilka utworów wcześniej przełożonych w ramach „Programu Wsparcia Tłumaczenia Literatury Światowej” Fundacji Daesan. Praca edytorska zaczęła się dopiero w 2006 roku. Czekając na wydanie, przetłumaczyłam dodatkowo 12 wierszy z tomiku Dwukropek z 2005 roku. Ostatecznie przełożyłam w sumie 217 utworów. Redakcja „Munji” wybrała 170 spośród nich. Tytuł całemu zbiorowi Kkeut-kwa sijak (Koniec i poczatek) nadało wydawnictwo.

11 W HUFS na zajęciach ze studentami koreańskimi czasami próbuję analizować wiersze Szymborskiej przez pryzmat filozofii Wschodu, ponieważ uważam, że dzięki takiej metodologii utwory, które moga być trudne do zrozumienia dla koreańskich studentów, da się przedstawić w sposób łatwy i ciekawy.

12 Seria ta odniosła wielki sukces, ponieważ wyborem tekstów do przekładu zajmuje się ekspert, który studiował literaturę danego kraju. W Korei do lat osiemdziesiątych XX wieku tego typu kompletna seria była publikowana na wzór analogicznej serii japońskiej. Większość utworów tłumaczono nie bezpośrednio $z$ danego języka, ale $z$ japońskiego lub $z$ angielskiego. 


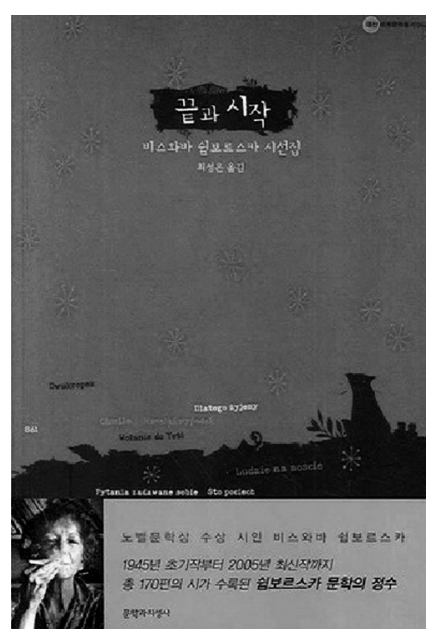

Okładka antologii poezji Szymborskiej Koniec i początek w wersji koreańskiej

Antologia Koniec i poczatek nie cieszyła się bezpośrednio po opublikowaniu zbyt wielkim zainteresowaniem w Korei. Edycja książki nie zbiegła się z żadnym wydarzeniem, które pomogłoby rozpropagować w tym kraju poezję Szymborskiej. Co więcej, antologia ukazała się w „Serii Światowej Literatury Pięknej Daesan”, na której temat czytelnicy mają stereotypowe zdanie, że w jej skład wchodzą utwory klasyczne, czyli trudne, a przez to nie dla każdego ciekawe. Wszystko to nie zachęcało do zakupu książki. Dodatkowo - ma ona stosunkowo dużą objętość: liczy 505 stronic (zawiera 170 wierszy, przemówienie noblowskie Szymborskiej, kalendarium jej życia i twórczości oraz słowo od tłumaczki).

Jednak po upływie roku ukazało się drugie wydanie antologii. W tym miejscu warto zwrócić uwagę na fakt, że od 2008 roku uznani i cenieni koreańscy poeci lub pisarze coraz częśsiej cytowali wiersze Szymborskiej bądź komentowali jej twórczość i biografię. Dzięki temu czytelnicy koreańscy zaczęli interesować się tomem Koniec i poczatek. W roku 2009 wzrosła jego sprzedaż oraz liczba pozytywnych recenzji i opinii na jego temat zamieszczanych w prasie, jak też w Internecie. Ludzie z ust do ust przekazywali sobie informację o książce i w ten sposób stała się ona znana wśród szerszych kręgów czytelników. Od roku 2009 antologia miała kolejne wydania niemal co cztery miesiące. W grudniu 2012 pojawiła się na rynku edycja 12 (w Korei Południowej nakład każdego kolejnego wydania wynosi 1000-2000 egzemplarzy, a więc do 1 IV 2013 sprzedano w sumie 12000 egzemplarzy tej książki). Antologia poezji Szymborskiej stała się tzw. steady sellerem. W koreańskim świecie wydawniczym mówi się, że jest to naprawdę wyjątkowe zjawisko.

Poza tym Koniec i początek znalazł się na ogłaszanej przez koreańskie Ministerstwo Kultury i Turystyki prestiżowej liście „Książki Roku” - za rok 2007.

$$
\text { Recenzje antologii Koniec i poczatek }
$$

Wkrótce po opublikowaniu antologii Koniec i poczatek, w lipcu 2007, jako pierwsza informację o niej przekazała koreańska agencja prasowa „Yonhap News”. Potem 
drukowano krótkie doniesienia na jej temat niemal we wszystkich ważniejszych dziennikach i czasopismach. 30 XI 2007 książka została przedstawiona w wiadomościach telewizji SBS. W programie tym recytowano dwa utwory: Nic dwa razy i Miłość szczęśliwa ${ }^{13}$.

Wśród omówień ogłoszonych w prasie $\mathrm{z}$ tego okresu na szczególną uwagę zasługuje artykuł napisany przez bardzo znanego powieściopisarza młodego pokolenia, Kim Yeon Su, w dzienniku „Donga Ilbo”, w numerze z 1 X 2007. Akurat wtedy dziennik ten drukował serię relacji zatytułowanych Siin-kwa soseolka-ga chucheonhaneun kaeul siseon 20kwon (20 tomów poezji na jesień, rekomendowanych przez poetów i prozaików). W swoim felietonie Kim Yeon Su wybrał do omówienia właśnie książkę Szymborskiej i polecał ja jako zbiór poezji, który koniecznie należy przeczytać. Cytując kilka wierszy Szymborskiej, m.in. Tortury, Muzeum, Pod jedna gwiazdka, Nic dwa razy, Kim Yeon Su stwierdził:

Dzięki książce Koniec i początek autorstwa polskiej poetki Wisławy Szymborskiej możemy zrozumieć, dlaczego się uśmiechamy akurat teraz, a nie kiedy indziej, np. w przeszłości czy w przyszłości. Zrozumiemy również, dlaczego akurat tutaj, a nie gdzie indziej. Poetka zdała sobie sprawę $z$ tego faktu w muzeum. Dla niej muzeum to miejsce, w którym pokazuje się śmiertelny los człowieka, a nie los starych eksponatów.

W końcu nikt z nas, ludzi, nie może uciec od takiego przeznaczenia. Jeżeli chcemy się uśmiechać, musimy zrobić to teraz i tutaj. [...] Jesteśmy ludźmi, więc mamy tylko do wyboru: być szczęśliwymi tutaj albo nie być szczęśliwymi tutaj ${ }^{14}$.

Kim Yeon Su swoją kolejną recenzję antologii Koniec i poczatek, opublikowana w październiku 2012, zatytułował Uri-neun neul uri bakkat-e jonjaehanda (Jesteśmy zawsze na zewnatrz naszej istoty). Autor wymienia tam takie utwory Szymborskiej, jak Album, Ścięcie, Muzeum, Dworzec, Podjedna gwiazda, Podziękowanie, Nic dwa razy, Tortury. Kim Yeon Su niezwykle aprobatywnie odnosi się do przesłania poezji Szymborskiej, pisząc m.in.: „Swimboreuseuka-ui si-neun jonjaehaneun modeun keotdeul-ui ireum-eul hanahana bulleonaenda [Poezja Szymborskiej przywołuje imię każdego przedmiotu, który istnieje na świecie]" ${ }^{15}$.

Kolejną interesująca kwestią jest fakt, że recenzje antologii Koniec i początek ukazywały się nie tylko zaraz po jej wydaniu, ale były publikowane właściwie nieprzerwanie aż do teraz. Np. w maju 2008 Ku Bong Hyung, który nie jest ani pisarzem, ani krytykiem, lecz znanym konsultantem w zakresie zarządzania i marketingu, $\mathrm{z}$ całym przekonaniem rekomendował tę antologie $\mathrm{w}$ gazecie ekonomicznej „Ikonomik Ribyu” / „Economic Review”:

Czuję żal. Dlaczego nie ma żadnego tomu poezji na liście bestsellerów? Całą tę listę wypełniaja tylko poradniki radzace, jak skutecznie dokonywać samorozwoju albo jak osiagać sukces finansowy.

Fragment wiadomości można przeczytać na stronie internetowej: http://news.sbs.co.kr/section_ news/news_read.jsp?news_id=N1000343750

14 Kim Ye on Su, Sïn-kwa soseolka-ga chucheonhaneun kaeul siseon 20kwon: je 5-hoe - Biseuwaba Swimboreuseuka "Kkeut-kwa sijak』(20 tomów poezji na jesień, rekomendowanych przez poetów i prozaików: nr 5 - „Koniec i początek” autorstwa Wisławy Szymborskiej). „Donga Ilbo” 2007, nr z 1 X.

15 Kim Yeon Su, Uri-neun neul uri bakkat-e jonjaehanda (Jesteśmy zawsze na zewnatrz naszej istoty). „Munhak-kwa Sahoe [Literatura i Społeczeństwo]” nr 79 (2007), s. 451. 
[...] Gdzie przepadły te piękne pieśni, które budziły naszego ducha? Dlaczego poezja została zamknięta w starym pudełku, którego nikt nie chce otworzyć?

Być może, jest ona na ogół trudna do zrozumienia? Wobec tego chciałbym przedstawić tom poezji napisany prostym, codziennym językiem. Ten tom przywodzi mi na myśl kuchnię albo pokój gościnny rodzinnego domu. [...] Poezja Szymborskiej jest łatwa w czytaniu, nawet dla osób, które tak jak ja nie są w ogóle związane ze światem poezji ${ }^{16}$.

Z punktu widzenia tłumacza najbardziej imponująca recenzją dotycząca tej książki jest felieton jednego $z$ najwybitniejszych obecnie w Korei krytyków literackich młodego pokolenia, Sin Hyung Chul. Ocenił on bardzo wysoko poziom przekładu wierszy zawartych w antologii. Swoja przychylną postawę wyraził już w samym tytule felietonu: Sangkwaehan tongchal, dajeonghan jihye: ,Incheon Gonghang'-eul musahi tongkwahan Biseuwaba Swimboreuseuka-ui siseonjip "Kkeut-kwa sijak (Głęboka przenikliwość, prosta madrość: Antologia poezji Wisławy Szymborskiej „Koniec i początek”, która bezpiecznie wyladowała na lotnisku Incheon):

Poezja jest w pewnym sensie drgnieniami zmysłów i gimnastyką znaczeń wyrazów. Pod tym względem czytanie wierszy tłumaczonych z języka obcego to daremny trud. Większa część tych drgnien zmysłów oraz prawie wszystkie przemieszczenia znaczeń wyrazów znikają podczas przenoszenia wierszy z jednego języka na drugi. Wszystko, co pozostaje w nowym języku, to opowieść i przesłanie. To z pewnościa przykre. Jednak mimo tych trudności i ograniczeń istnieją pewne wiersze przełożone $z$ jezzyka obcego, warte przeczytania, takie jak wiersze Szymborskiej.

[...] [tu przytoczone dwa wiersze: Album i Pisanie życiorysu]

Te dwa wiersze cytuję $z$ tomu Koniec i poczatek autorstwa Wisławy Szymborskiej, laureatki literackiej Nagrody Nobla w 1996 roku. Moim zdaniem, wiersze z tego tomu wylądowały cało i bezpiecznie na lotnisku Incheon. Nie tylko dlatego, że Choi Sung Eun (polonistyka, Hankuk University of Foreign Studies) świetnie je przetłumaczyła, ale również dlatego, że ich oryginalna wersja jest właśnie oparta na opowieści i przesłaniu.

[...] [przytoczone dwa wiersze: Miłość szczęśliwa i Żona Lota]

Dzięki głębokiej przenikliwości oraz prostej mądrości da się naprawdę pokochać tę grubą, 500-stronicową książkę. Serdecznie polecam ten tom osobom, które głęboko się rozczarowały lekturą poezji Rimbauda tłumaczonych na koreański i całkowicie straciły chęć do czytania jakiegokolwiek tomu wierszy przełożonych $\mathrm{z}$ innego języka ${ }^{17}$.

Jedna $z$ osób, które naprawdę bardzo przysłużyły się przybliżaniu antologii Koniec i poczatek koreańskim czytelnikom, to Cheong Hye Yun. Jest ona producentem radiowym w stacji CBS, a równocześnie znaną felietonistką literacką. Wielu czytelników bez wahania kupuje książki polecane przez nią w felietonach. I właśnie dzięki temu, że Cheong Hye Yun przy różnych okazjach wyrażała swoje wielkie upodobanie do poezji Szymborskiej, wiele osób zainteresowało się antologia Koniec i poczatek. Oto cytat z głośnej książki Cheong, pod dość ekstrawaganckim tytułem Chimdae-wa chaek-jisang-eseo kajang kwanneungjeokin dokseogi (Łóżko i ksiażki - najerotyczniejszy zapis czytania ksiażek na świecie):

Ku Bon Hyung, Kkotpineun bom si-reul ikja (Przeczytajmy poezję wiosna petna kwiatów). „Economic Review” 2008, nr z 4 V (rubryka Book Review).

17 Sin Hyung Chul, Sangkwaehan tongchal, dajeonghan jihye: ,Incheon Gonghang'-eul musahi tongkwahan Biseuwaba Swimboreuseuka-ui siseonjip "Kkeut-kwa sijak』(Gtęboka przenikliwość, prosta madrość: Antologia poezji Wisławy Szymborskiej „Koniec i początek”, która bezpiecznie wyladowała na lotnisku Incheon). „Hangyore 21” nr 74 (2009), z 25 II. 
Szymborska mówi nam, dla których miłość niedawno się skończyła, o znaczeniu podziękowania:

„Wiele zawdzięczam

tym, których nie kocham” (Podziękowanie)

Poetka do nas szepcze:

„Przenigdy nie zdołałaby zaludnić ziemi

[miłość szczęśliwa] zdarza się przecież rzadko” (Miłość szczęśliwa)

O szczęściu opowiada tak:

„A mnie tak się złożyło, że jestem przy tobie.

I doprawdy nie widzę w tym nic

zwyczajnego"

(*** 〈Nicość przenicowała się także i dla mnie...〉)

Zamykam książkę Szymborskiej, marząc o tym, by kiedy się zestarzeję, być tak fantastyczną babcią, jaką jest ona. To, co mamy zrobić po zakończeniu miłości, zostało zapisane jako pierwsze zdanie jej wiersza Koniec i poczatek:

„Po każdej wojnie

ktoś musi posprzątać” (Koniec i początek)

Czy istnieje ktoś, kto nie przeżywa własnej wojny w życiu? Teraz nadszedł czas sprzątania! ${ }^{18}$

W grudniu 2010 antologia Koniec i początek ponownie przykuła uwage środków masowego przekazu w Korei. Wtedy „Seria Światowej Literatury Pięknej Daesan” świętowała wydanie setnego tytułu. Temu wydarzeniu towarzyszyły różne akcje promocyjne przygotowane przez wydawnictwo „Munji”, celebrujące sukces serii.

Wszystkie najważniejsze dzienniki, takie jak „Chosun Ilbo”, „Hangyore”, „Joongang Ilbo”, „Donga Ilbo”, równocześnie zamieściły artykuły na temat serii. Prasa koreańska podkreślała: „Do tej serii należą utwory bez wątpienia istotne w historii literatury światowej, a zarazem trudno dostępne na rynku koreańskim" 19 . Jako przykład tytułu z „Serii Światowej Literatury Pięknej Daesan” cieszącego się największą popularnością podawano właśnie Koniec i początek Wisławy Szymborskiej obok tomu poezji Charles'a Baudelaire’a Kwiaty zła ${ }^{20}$.

\section{Wpływ na koreańskich pisarzy}

Niewątpliwie głównym powodem popularności tomu Koniec i początek w Korei jest zainteresowanie poetów i prozaików koreańskich poezją Szymborskiej oraz ich częste komentarze na temat jej wierszy formułowane przy różnych okazjach.

Do koreańskich pisarzy wyrażajacych swoje zamiłowanie do poezji Szymborskiej należą tak wybitni i znani twórcy, jak powieściopisarz Kim Yeon Su, o którym już wcześniej była mowa, powieściopisarki Pyun Hye Young i Chung Yi Hyun, poetki Jin Eun Young, Kang Eun Kyo i Chung Kut Byol oraz poeta Chang Seok Nam.

Cheong Hye Yun, Chimdae-wa chaek-jisang-eseo kajang kwanneungjeokin dokseogi (tóżko i ksiażki - najerotyczniejszy zapis czytania książek na świecie). Seul 2007, s. 135-136.

19 Yi Hun Sung, Daesan Segye Munhak Chongseo: 16kae eoneokwon, chamsinhan jakpum sogae („Seria Światowej Literatury Pięknej Daesan”: przedstawienie nowych arcydzieł z 16 języków). „Hankuk Ilbo” 2010, nr z 19 XII.

20 W niektórych gazetach wymieniano oprócz tych dwóch książek jeszcze następujące publikacje: I. Andrić, Most na Drinie. - Natsume Sōseki, Serce. 
Jin Eun Young, poetka młodego pokolenia, w swoim felietonie Nae insaeng-ui chaek - Biseuwaba Swimboreuseuka "Kkeut-kwa sijak』 (Jedyna ksiażka mojego życia - „Koniec i poczatek” Wisławy Szymborskiej), zamieszczonym w dzienniku „Hangyore”, wypowiadała się o antologii Szymborskiej następująco:

Jeżeli poezja jest w jakimś sensie owocem, to wiersze Szymborskiej chyba mogłyby być takim owocem, który dał mi wielką radość dzielenia się nim możliwie ze wszystkimi. [...]

Podczas zajęć popołudniowych, kiedy studenci drzemią, zapisuję na tablicy zawsze jeden wiersz.

[...] [tu przytoczony wiersz Nic dwa razy]

Wtedy proszę studenta wyglądającego na zmęczonego o przeczytanie na głos tego wiersza. Po wysłuchaniu wiersza Szymborskiej studenci z błyskiem w oku zaczynają przyglądać się tej książce oraz światu. Mój ulubiony wiersz z tego tomu to Możliwości ${ }^{21}$.

W innym felietonie, Si-ro yeoneun achim (Poranek otworzony poezja), zamieszczonym w dzienniku „Hankuk Ilbo”, Jin Eun Young przedstawiła wiersz Szymborskiej Pomytka ${ }^{22}$

Także bardzo znana powieściopisarka Pyun Hye Young wielokrotnie w różnych wypowiedziach przyznawała, że jest miłośniczką poezji Szymborskiej:

Kiedy pisze powieść, czasami tracę pewność siebie oraz siły do pisania, ponieważ po prostu na świecie znajduje się za dużo rzeczy niepoznawalnych i niezrozumiałych. Tym bardziej nie umiem odczytać serca człowieka, bo serce każdego z nas jest tak bardzo odrębne. Wtedy, kiedy czuję granicę swoich możliwości, zawsze sięgam po książkę Szymborskiej. Są tam oczywiście jej przepiękne wiersze, które ironicznie pokazują współistnienie początku i końca, życie towarzyszące śmierci, tragiczne zakończenie ukryte w szczęśliwej miłości. Jednak jej odczyt noblowski ze Sztokholmu stanowi dla mnie, utyskującej często na pisanie, zawsze najlepsze lekarstwo. [...]

Według Szymborskiej poeta jest kimś, kto bezustannie mówi do siebie: „nie wiem”, a jednocześnie kimś, kto stara się bez przerwy odpowiedzieć na pytania zadawane sobie. Jej odczyt zawsze dodaje mi otuchy i pociechy. [...]

Tylko wtedy, kiedy umiemy powiedzieć: „nie wiem”, zaczynamy rozmawiać z innymi, czytać książki i coś badać. W ten sposób można sięgnąć po „natchnienie”, które zmieni świat ${ }^{23}$.

Pyun Hye Young ponadto w swojej powieści Jae-wa ppalgang (Popiót i czerwień), wydanej w 2010 roku, umieściła fragment $\mathrm{z}$ wiersza Szymborskiej Nic darowane: „Będę zmuszona sobą / zapłacić za siebie, / za życie oddać życie”. W czasie wywiadu prasowego autorka stwierdziła:

Chciałam wyraźnie pokazać ironię życia poprzez kreację mojego bohatera, który im lepiej chce coś zrobić, tym głębiej wpada w kłopoty. Żeby wyrazić symbolicznie tę moją intencję, zacytowałam wprost właśnie wiersz Szymborskiej ${ }^{24}$.

Jest to dobry przykład na to, że poezja Szymborskiej zaczyna odgrywać ważną

J in E un Young, Nae insaeng-ui chaek-Biseuwaba Swimboreuseuka "Kkeut-kwa sijak』(Jedyna ksiażka mojego życia - „Koniec i poczatek” Wisławy Szymborskiej). „Hangyore” 2010, nr z 4 VI. J in E u n Young, Si-ro yeoneun achim: „Silsu” - Biseuwaba Swimboreuseuka (Poranek otworzony poezja: „Pomytka” - Wistawa Szymborska). „Hankuk Ilbo” 2012, nr z 25 I.

23 Pyun Hy e Young, „na-neun moreugesseo” („, nie wiem”). „Hankuk Ilbo” 2009, nr z 23 VI (rubryka Salm-kwa munhwa 〈Życie i kultura〉).

24 Cyt. za: Yi Hun Sung, Pyun Hye Young 『Jae-wa ppalgang»: Jal nagada migung sok-euro... Insaeng-iran cham! (Pyung Hye Young, „Popiół i czerwień”: Ze szczytu w przepaść... Takie to życie!). „Hankuk Ilbo” 2010, nr z 28 II. 
rolę w pracy twórców koreańskich, stając się motywacją twórczą albo natchnieniem do pisania.

Chung Yi Hyun, powieściopisarka młodego pokolenia, której twórczość cieszy się uznaniem wielu stałych czytelników (szczególnie dziewcząt) dzięki popularności swojej pierwszej powieści, Talkomhan na-ui tosi (Moje słodkie miasto), wydanej w roku $2006^{25}$, jest również wielką miłośniczką poezji Szymborskiej. Autorka zacytowała fragment wiersza Szymborskiej Fotografia z 11 września w posłowiu do swojej drugiej powieści, Neo-neun moreunda (Nie wiesz), wydanej w roku 2011:

Naprawdę trudno mi pisać posłowie do mojej książki. Napisałam ją z sercem, i to wszystko. Sama najlepiej wiem, że na tym świecie nie wolno dać żadnego pretekstu. Pomimo wszystko trochę się boję. Pani Szymborska, którą uwielbiam, kiedyś powiedziała tak:

„Tylko dwie rzeczy mogę dla nich [tj. ofiar zamachu z 11 września] zrobić - opisać ten lot i nie dodawać ostatniego zdania".

Ja też chciałabym tak zrobić, pragnąc jednak, by moi bohaterowie żyli na świecie pełnią swojego życia, poza zasięgiem ostatniego mojego zdania ${ }^{26}$.

Znany krytyk literacki oraz eseista Yi Guang Ho w swoim zbiorze esejów Sarang-ui mirae (Przyszłość miłości) z 2011 roku snuł rozważania nad znaczeniem miłości, cytując wiele wierszy napisanych przez różnych poetów, m.in. przez Szymborską. Tak więc np. autor po przytoczeniu wiersza Szymborskiej Niespodziane spotkanie opowiada historię pewnej pary, której nie udaje się porozumieć nawet podczas rozmowy. W ten sposób uwypukla zasadniczą różnicę między kobietą a mężczyzną:

Oto wiersz Wisławy Szymborskiej pt. Niespodziane spotkanie:

$$
\begin{aligned}
& \text { „Milkniemy w połowie zdania } \\
& \text { bez ratunku uśmiechnięci. } \\
& \text { Nasi ludzie } \\
& \text { nie umieją mówić z sobą”. }
\end{aligned}
$$

Dla Niego rozmowa oznacza drogę do celu, Ona zaś ma obsesję na punkcie znaczenia porozumiewania się. Pewnego dnia, kiedy Ona odczuła Jego znużenie i zmęczenie, ta niewielka różnica między nimi stała się nagle poważną barierą. A On wtedy chciał, żeby Ona przestała trajkotać i tylko całowała go. W momencie gdy ich wzajemne żądania zaczęły się różnić, świat ich własnego języka zaczął się rozpadać 27 .

Poeta Sang Hui Gu, który jest mało znany w porównaniu z innymi autorami tu przedstawionymi, napisał w roku 2008 utwór Biseuraba Swimboreuseuka (Wisława Szymborska) ${ }^{28}$. Przytaczam go w całości:

\section{WISEAWA SZYMBORSKA \\ Po przeczytaniu wiersza „Możliwości”}

Wszystko z powodu tej staruszki o niebywałej przenikliwości obserwacji. Nawet nakrywaniu do stołu poświęciłem wiele uwagi. Okazała zastawa stołowa, stylowe zasłony, a do tego gustowne świecz-

Sprzedano ponad milion egzemplarzy tej powieści.

Chung Yi Hyun, Neo-neun moreunda (Nie wiesz). Seul 2009, s. 487.

Yi Guang Ho, Sarang-ui mirae (Przyszłość miłości). Seul 2011, s. 68.

W tytule tym imię poetki zostało zapisane jako „비스라바 [Biseuraba]”. Jest to fonetycznie niepoprawne. 
niki, lśniący żyrandol i podniosła muzyka, nie wspominając już o dostojnych gościach w eleganckich strojach i o wyszukanych potrawach - wszystko dla niej.

A jej (widziałem to w oczach) jakby czegoś brakowało.

Zapytałem więc:

- Zje Pani coś jeszcze?

Staruszka zaprzeczyła głową.

- Może zmienię Mozarta na Oliviera Messiaena?

Staruszka zirytowała się.

- A może wyjmę porcelanę używaną niegdyś przez rodzinę carską z Petersburga? Właśnie przygotowujemy wykwintne potrawy $\mathrm{z}$ zachodnich krańców Chin.

Staruszka nawet nie drgnęła.

Ogarnęło mnie lekkie zniecierpliwienie, ale kontynuowałem.

- Może przyprowadzę mnicha Anandę 29 ?

Staruszka jakby się ożywiła. Nie było to jednak pełne zadowolenie.

- A może świętego Pawła albo Mahometa? Wtedy poczuje się Pani zaszczycona, prawda?

Staruszka poweselała. Nadal jednak coś jej nie odpowiadało.

- To może przyprowadzę Leonarda da Vinci? Nieprzeciętna postać, prawda?

Staruszka $\mathrm{z}$ radości klasnęła $\mathrm{w}$ dłonie.

Pod postacią staruszki kryje się wyobrażenie poety o Szymborskiej, która się ożywia dopiero przy Leonardzie da Vinci, symbolizującym humanistyczną wszechstronność i głód obserwacji rzeczywistości.

\section{Reakcje czytelników}

Coraz więcej koreańskich czytelników interesuje się poezją Szymborskiej dzięki znanym pisarzom i ich komentarzom na jej temat czy też twórczemu nawiązywaniu do niej w ich tekstach.

1 IV 2013 spróbowałam poszukać komentarzy pod hasłem „Szymborska” na najpopularniejszym koreańskim portalu internetowym www.naver.com ${ }^{30}$. Znalazłam tam 1605 komentarzy dotyczących twórczości poetki, jak też recenzji antologii Koniec i poczatek, zamieszczanych w blogach lub na prywatnych stronach domowych internautów.

Oto lista najczęściej cytowanych wierszy Szymborskiej oraz liczba komentarzy na ich temat:

1) Nic dwa razy (340);

2) Miłość od pierwszego wejrzenia (107);

3) Możliwości (98);

4) Zdumienie (52);

5) Trzy słowa najdziwniejsze (38).

Podam jako przykład kilka interesujących komentarzy czytelników, które zaczerpnęłam $\mathrm{z}$ ich blogów: Siakjamuniego, odznaczający się bardzo chłonną pamięcią; przypisuje mu się autorstwo wielu świętych tekstów.

30 Jeżeli poszukamy pod hasłem, 쉼보르스카 [Swimboreuseuka]”, znajdziemy 1284 komentarze, a pod hasłem ,심보르스카 [Simboreuseuka]" - 321 komentarzy. 
Wczoraj opuściłem szpital. Leżałem tam przez 5 i pół miesiąca. Kiedy byłem na oddziale urazowym, zawieszony między życiem a śmiercią, odwiedzało mnie naprawdę wiele osób.

Pewnego dnia koleżanka Sumi przeczytała mi kilka wierszy z tomu Koniec i poczatek Wisławy Szymborskiej. Następnego dnia inna koleżanka, Jae Yeon, wręczyła mi właśnie ten tom jako prezent. (Co to za niesamowity przypadek!)

Wczoraj po drodze do domu w samochodzie czytałem jeszcze raz moje ulubione wiersze Szymborskiej i nagle zakręciły mi się łzy w oczach. Tak, muszę zacząć żyć od nowa! W tym roku najpierw powinienem zadbać o zdrowie, a potem dopiero zastanowić się, co będę robić w przyszłym roku. Cytuję jeden wiersz z tomu Koniec i początek, który wywarł na mnie wielkie wrażenie.

[...] [tu zacytowany wiersz Wielkie to szczęście] [ID: wimwenders (13 IX 2009)]

W poezji Szymborskiej, a nie w jakiejkolwiek religii, odnajduje prawdziwy spokój ducha. Całe szczęście, że Szymborska jest obok mnie i dodaje mi otuchy - w takim dniu jak dzisiaj, kiedy wiatr silnie wieje i kiedy jest mi trudno zebrać myśli. [ID: khk02211 (12 III 2010)]

Pewnej nocy tom Koniec i poczatek zbliżył się do mnie trochę niespodziewanie, trochę mgliście i trochę jakby za sprawą przeznaczenia. Do tej pory nigdy nie doświadczyłam czegoś podobnego, więc jest mi trudno wytłumaczyć, jakie to uczucie. Mogę tylko powiedzieć, że to coś nadzwyczajnego, wyjątkowego, coś, co będę pamiętać przez długi, długi czas... I od tej nocy czuję, że moje życie jest jakby wielkim darem. Za każdym razem, kiedy otwieram książkę, mogę znaleźć słowa przezroczyste i czyste jak woda z głębokiej studni. Od tego czasu sięgam bardzo często po tę książkę i zagłębiam w niej swoje dłonie, aby czerpać wodę. Według mnie istnieje w tej książce tylko początek - końca nie ma. [ID: yuanzhou (19 VI 2011)]

\section{Prace naukowe o twórczości Szymborskiej}

Od momentu wydania antologii Koniec i początek (2 VII 2007) do 1 IV 2013 ukazały się w Korei cztery artykuły naukowe poświęcone twórczości Wisławy Szymborskiej. Trzy z nich zostały napisane przeze mnie, a jeden przez koreanistę:

\begin{tabular}{|c|c|c|c|c|c|c|}
\hline & Tytuł koreański & Tytuł polski & Czasopismo & Rok & Autor & $\begin{array}{l}\text { Dziedzina } \\
\text { nauki }\end{array}$ \\
\hline 1 & $\begin{array}{c}\text { Biseuwaba Swimboreu- } \\
\text { seuka-ui si-e natanan } \\
\text { hoehwajeok motibeu } \\
\text { yeongu }\end{array}$ & $\begin{array}{c}\text { Motywy malarskie } \\
\text { w poezji Wistawy } \\
\text { Szymborskiej }\end{array}$ & $\begin{array}{l}\text {,Segye Munhak } \\
\text { Bigyo Yeongu”/ } \\
\text { „Comparative } \\
\text { Study of World } \\
\text { Literature” nr } 22\end{array}$ & 2008 & $\begin{array}{l}\text { Choi } \\
\text { Sung } \\
\text { Eun } \\
\text { (Estera } \\
\text { Czoj) }\end{array}$ & $\begin{array}{l}\text { Polonistyka } \\
\text { (HUFS) }\end{array}$ \\
\hline 2 & $\begin{array}{c}\text { Biseuwaba Swimboreu- } \\
\text { seuka-ui }{ }^{\text {Kollon』-e }} \\
\text { natanan paereodijeok } \\
\text { yoso yeongu }\end{array}$ & $\begin{array}{l}\text { Elementy parodii } \\
\text { odnalezione } \\
w \text { tomiku „Dwukro- } \\
\text { pek” Wisławy } \\
\text { Szymborskiej }\end{array}$ & $\begin{array}{c}\text { „Dongyureop } \\
\text { Balkanhak” / } \\
\text { „Journal of Central } \\
\text { \& East European } \\
\text { Studies” t. 10, nr 1 }\end{array}$ & 2008 & $\begin{array}{l}\text { Choi } \\
\text { Sung } \\
\text { Eun } \\
\text { (Estera } \\
\text { Czoj) }\end{array}$ & $\begin{array}{l}\text { Polonistyka } \\
\text { (HUFS) }\end{array}$ \\
\hline 3 & $\begin{array}{c}\text { O Kyu Won-kwa } \\
\text { Biseuwaba Swimboreu- } \\
\text { seuka-ui sijakpum bigyo } \\
\text { yeongu }\end{array}$ & $\begin{array}{l}\text { Studium kompara- } \\
\text { tystyczne nad } \\
\text { poezja Szymbor- } \\
\text { skiej i O Kyu Wona }\end{array}$ & $\begin{array}{l}\text { „Segye Munhak } \\
\text { Bigyo Yeongu” / } \\
\text { „Comparative } \\
\text { Study of World } \\
\text { Literature” nr } 28\end{array}$ & 2009 & $\begin{array}{l}\text { Shin Ju } \\
\text { Cheol }\end{array}$ & $\begin{array}{c}\text { Koreanisty- } \\
\text { ka } \\
\text { (HUFS) }\end{array}$ \\
\hline 4 & $\begin{array}{l}\text { Biseuwaba Swimboreu- } \\
\text { seuka-ui munhakkwan }\end{array}$ & $\begin{array}{c}\text { Poglady literackie } \\
\text { Wisławy Szymbor- } \\
\text { skiej }\end{array}$ & $\begin{array}{c}\text { „Weokuk Munhak } \\
\text { Yeongu” / „Foreign } \\
\text { Literature Studies” } \\
\text { nr } 36\end{array}$ & 2009 & $\begin{array}{l}\text { Choi } \\
\text { Sung } \\
\text { Eun } \\
\text { (Estera } \\
\text { Czoj) }\end{array}$ & $\begin{array}{l}\text { Polonistyka } \\
\text { (HUFS) }\end{array}$ \\
\hline
\end{tabular}


Sin Ju Cheol, który jest koreanistą, dokonał próby interesującej analizy porównawczej wybranych wierszy koreańskiego poety O Kyu Wona i wybranych utworów Szymborskiej, takich jak Widok z ziarnkiem piasku, Zdumienie, Trzy słowa najdziwniejsze. Sin Ju Cheol wskazał na świadomość ograniczeń oraz ułomności języka jako na coś, co zbliża teksty poetyckie tych dwojga autorów. Według niego zarówno Szymborska, jak O Kyu Won prezentują w swojej twórczości przeświadczenie, że możliwe jest dosięgnięcie powierzchni jakiejś rzeczy za pomoca symbolicznego systemu języka, który jednak nie pozwala dotrzeć do prawdziwej natury rzeczy, jej esencji ${ }^{31}$.

Badania nad poezją Szymborskiej nie zamykają się w granicach polonistyki, przeciwnie - wkraczają na obszar pozostałych filologii. Nie ulega wątpliwości, że wpływ na to ma sukces, jaki odniosła antologia Koniec i początek wśród odbiorców w Korei.

\section{Wpływ na inne gatunki sztuki oraz recepcja w kontekstach społecznych}

Poezja Szymborskiej nie tylko ma duże znaczenie w kręgach związanych z literaturą lub nauką, ale wykazuje również wpływ na działania twórcze w dziedzinie sztuki.

Jako przykład podam film Kkeut-kwa sijak (Koniec i poczatek), w reżyserii Min Kyu Donga, przedstawiony w prestiżowej sekcji Gala Presentation na Międzynarodowym Festiwalu Filmowym (BIFF) w Busan w 2009 roku. Film ten traktuje o nietypowej relacji między dwiema kobietami - żoną, która traci męża w wypadku, oraz dziewczyną, która przyznaje się, że była jego kochanką. Dziewczyna chce dzielić z żoną rozpacz po ich najdroższym. Nie zraża się tym, że żona, zaszokowana zdradą męża, próbuje ją odtrącić. Jednak dziewczyna swoją opiekuńczością i oddaniem dla żony ostatecznie zaskarbia sobie jej przychylność. Te dwie kobiety, które razem dzielą tęsknotę za jednym mężczyzną, doświadczają poczucia wspólnoty oraz ambiwalentnych emocji. W końcu stają się sobie niezbędne i nie potrafią już bez siebie żyć.

Reżyser Min Kyu Dong, który sam napisał scenariusz tego filmu, ujawnił w czasie wywiadu, że inspiracją dla niego była właśnie antologia Koniec i poczatek ${ }^{32}$. Twórca chciał dowieść, iż śmierć nie oznacza końca, ale może być początkiem wtedy, kiedy budzi wolę życia u innych ludzi.

W dniach 15-16 X 2010 w Seoul Art Center (Seulskie Centrum Sztuki) odbył się nietypowy spektakl baletowy, zatytułowany Si-reul ilneun sigan (Czas na poezję), w wykonaniu Chang Sun Hee Balledan (Zespołu Baletowego Chang Sun Hee). Tancerze przedstawili 8 układów choreograficznych na podstawie 8 wybranych

31 Sin J u Ch e ol, O Kyu Won-kwa Biseuwaba Swimboreuseuka-ui sijakpum bigyo yeongu (Studium komparastyczne nad poezja Szymborskiej i O Kyu Wona). „Segye Munhak Bigyo Yeongu” / „Comparative Study of World Literature" nr 28 (2009).

32 Zob. Ki m Suk Hy u n, Kkeut-kwa sijak, hokeun han namja-reul saranghan du yeoja-ui aejeung (Koniec i poczatek, albo ambiwalentne uczucie dwóch kobiet zakochujacych się w jednym mężczyźnie). „Peuresian” / „Pressian” 2009, nr z 12 X (rubryka BIFF 2009). 
wierszy Szymborskiej, m.in. Możliwości. Tym samym poezja Szymborskiej została wyrażona mową ciała ludzkiego.

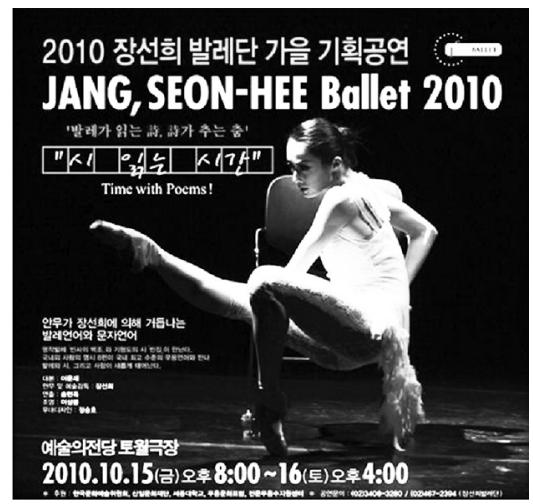

Plakat ze spektaklu baletowego Czas na poezję

Poezję Szymborskiej zaczęto dość często cytować, interpretować i rozumieć nie tylko w obszarze literatury i sztuki, ale również w szerszych kontekstach społecznych. Np. znany powieściopisarz Kim Chung Hyeok w swoim felietonie na temat problematyki społecznej cytował wiersz Szymborskiej Psalm.

W roku 2009 rząd koreański ogłosił „Projekt przebudowy dzielnicy Yongsan” i siłą wysiedlił jej mieszkańców. Na skutek brutalnego sposobu postępowania władz liczni mieszkańcy wzięli udział w protestach przeciw temu projektowi i urządzili dość agresywną demonstrację. Policja w końcu ją stłumiła przemocą, zginęło 6 osób, a 23 osoby zostały ranne. W swoim felietonie, wypowiedzi mocno krytycznej wobec rządu koreańskiego, Kim Chung Hyeok powołuje się na wiersz Szymborskiej:

Jest jesień. Gdy patrzę na wysokie i odległe niebo, gdy próbuję dotknąc na nim białych chmur i świeżego powietrza, przekonuję się, że wszyscy żyjemy w wielkim kosmosie. Do takiego nieba pasuje poezja. Kiedy spojrzałem w niebo, nagle dało się słyszeć głos Wisławy Szymborskiej, poetki polskiej:

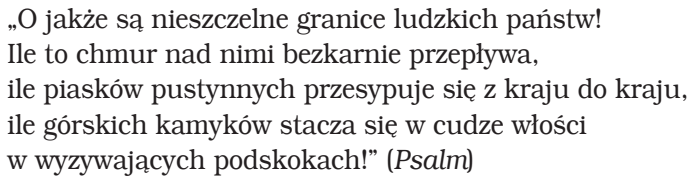

Im wyżej jest niebo, tym banalniejsze wydają się te sztuczne linie zaznaczone przez ludzi na ziemi. Na pewno nie patrzą na niebo ci, którzy wymyślili podziały na ziemi, wysiedlili innych i przyparli ich na koniec do ziemi ${ }^{33}$.

W drugiej połowie roku 2012, przed wyborami prezydenckimi (19 XII 2012), agresja i napastliwość kandydatów na prezydenta stała się gorącym tematem koreańskiej debaty społecznej. Felietonista O Gil Young, mając krytyczny stosunek do takiej strategii kandydatów, odwołał się do poezji Szymborskiej:

Serdecznie polecam kandydatom na prezydenta antologię poezji Szymborskiej Koniec i poczatek. 
Bardzo bym chciał mieć takiego męża stanu, który przeczytałby tę książkę i uświadomiłby sobie znaczenie prawdziwego porozumiewania się oraz ograniczenia ludzkiej mowy. Czyż nie nadszedł dla nas czas na takiego przywódcę? ${ }^{34}$

\section{Trzeci okres: po śmierci Wisławy Szymborskiej}

1 II 2012, kiedy zmarła Wisława Szymborska, niemal wszystkie dzienniki koreańskie zamieściły nekrologii w formie krótkich artykułów wspomnieniowych. Także wielu poetów, pisarzy i krytyków literackich wyrażało swój smutek. Wśród nich byli m.in. słynny poeta i krytyk literacki Kim U Chang, poeci Chang Seok Nam oraz Sim Bo Sun, poetki Mun Cheong Hee i Choi Cheong Rye. Publikowali oni przy różnych okazjach wzmianki na temat noblistki. Również wielu czytelników wierszy Szymborskiej okryło się żałobą po jej śmierci.

Przytoczmy tu jako przykład myśli Kim U Changa zamieszczone w jego artykule Modeun keos-i jeongchida - Swimboreuseuka-ui si (Wszystko mogłoby być polity$k a-$ poezja Szymborskiej), wypływające z lektury wierszy polskiej autorki, takich jak: Dzieci epoki, Może być bez tytułu, Album, Wrażenia z teatru, Muzeum, Wszelki wypadek, Terrorysta on patrzy, Widziane z góry, Urodziny, Do Arki, Nienawiść, Tutaj, Jarmak cudów:

Dla Szymborskiej ważniejsze okazują się drobne przejawy życia, a nie wielkie dzieje, polityka czy ideologia. Ironią jest jednak to, że podstawa indywidualnej egzystencji może być utrzymana tylko dzięki polityce. Wobec tego zainteresowanie drobnymi przejawami życia to ważna nauka dla polityków. Prawdopodobnie Szymborska sama rozumiała to, że wszystko może być polityką w naszym życiu. Oto moja krótka myśl jako wyraz ubolewania nad odejściem wielkiej poetki ${ }^{35}$.

Wiersze Szymborskiej raczej słyna ze swojej apolityczności. Ale znaczenie egzystencji indywidualnej jednostki w społeczeństwie czy nawet w historii jest jedną z najistotniejszych kwestii socjologicznych jej poezji, więc uwagi Kim U Changa sa w jakimś sensie słuszne.

Poeta Sim Bo Sun wyraził swój smutek po śmierci poetki w artykule utrzymanym w dość osobistym tonie, Eoneu siin-ui pyeonghwaroun jukeum (Spokojne odejście pewnej poetki):

1 lutego polska poetka Wisława Szymborska, mając 88 lat. odeszła w pokoju. [...] Ta smutna wieść dotarła do mnie $z$ opóźnieniem.

Zawsze myślałem, że między Szymborską a mną oprócz faktu, że jestem miłośnikiem jej poezji, jest jeszcze coś, co nas łączy - otóż pierwsze dwie sylaby mojego i jej nazwiska brzmią podobnie. Nazywam się Sim Bo Sun, a ona Szym-bo-rska. Pewnego dnia dowiedziałem się, że także mój kolega uwielbia Szymborska. Wtedy powiedziałem mu tak: „Bardzo się cieszę, iż lubisz "moją polską ciocięu”. [...] Prasa przekazała taką wiadomość: „Szymborska zasnęła spokojnie w swoim domu”. Śpij sobie słodko, moja kochana polska ciociu!! 36

O Gil Young, Jeongchi-ui eoneo, si-ui eoneo (Mowa polityki, mowa poezji). „Hangyore” 2012, nr z 14 IX.

Kim U Chang, Modeun keos-i jeongchida-Swimboreuseuka-ui si (Wszystko mogłoby być polityka - poezja Szymborskiej). „Kyunghyangshinmun” 2012, nr z 13 II.

Sim Bo S u n, Eoneu siin-ui pyeonghwaroun jukeum (Spokojne odejście pewnej poetki). „Hankuk Ilbo" 2012, nr z 16 II (rubryka Salm-kwa Munhwa 〈Życie i kultura〉). 


\section{Podsumowanie}

Wisława Szymborska zyskała rozgłos w Korei Południowej dopiero po otrzymaniu literackiej Nagrody Nobla w 1996 roku. Po wydaniu antologii Koniec i poczatek, zawierającej 170 wierszy przełożonych na język koreański, zbliżyła się do koreańskich czytelników. Najpierw zwrócili uwagę na antologię wybitni poeci i pisarze, a dzięki ich aktywności w propagowaniu tej poezji stała się ona ogólnie dostępna dla zwykłych odbiorców i odniosła wielki sukces w Korei. Wiersze Szymborskiej zaczęły motywować do działalności twórczej pisarzy i poetów, ale również przedstawicieli innych gatunków sztuki. Ponadto stały się punktem odniesienia dla koreańskich komentatorów istotnych wydarzeń politycznych i społecznych.

Taka sytuacja udowadnia, że w poezji Szymborskiej jest coś, co przyciaga koreańskich czytelników do jej lektury. Poezja ta zawiera elemety, które są bliskie naszej mentalności oraz filozofii Wschodu. Czytając wiersze Szymborskiej, możemy doznać czasami takiego uczucia, jakbyśmy stanęli wobec pustego miejsca poza logiką i percepcja. Takie puste miejsce, podobnie jak pustka wypełniająca całe tło obrazu w malarstwie Dalekiego Wschodu, zachęca odbiorców w sposób naturalny do współczucia, wzajemnego zrozumienia i dialogu. W tej pustej przestrzeni czytelnicy mogą mieć okazję do spokojnego razważania i metafizycznej medytacji. Prawdopodobnie dlatego Koreańczykom spodobał się zbiór poezji noblistki ${ }^{37}$.

Po śmierci poetki wielu pisarzy, krytyków literackich, naukowców i zwykłych odbiorców wciąż czyta jej wiersze oraz je cytuje, wspomina i interpretuje. W związku z tym można powiedzieć, że recepcja poezji Szymborskiej w Korei trwa i bezustannie ewoluuje. W przygotowaniu sa kolejne przekłady mojego autorstwa - dwa tomy wierszy: Tutaj (2009) i Wystarczy (2012), które ukażą się nakładem wydawnictwa „Munji”.

\section{Abstract \\ CHOI SUNG EUN (ESTERA CZOJ) Hankuk University of Foreign Studies, Seoul}

\section{RECEPTION OF WISŁAWA SZYMBORSKA'S POETRY IN THE REPUBLIC OF KOREA}

Wisława Szymborska first became known in Korea after she won the Nobel Prize in Literature in 1996, but came closer to readers with the publication of her poetry book entitled The End and the Beginning (including 170 poems) in 2007. The Korean version of Szymborska's poetry book first drew attention of Korean poets and novelists and, later, owing to their active introduction of the book to Korea, her poems became very popular among general public as well. Her poetry book The End and the Beginning went through twelve editions in Korea, and more than 12000 copies have been sold as the book has become a steady seller. Immediately after the publication of the book, her poems were simply read, cited and critiqued, but later they were used as motifs in the creation of literary works which went on to influence other genres such as film, ballet, and photography. Furthermore, Szymborska's poems have been cited and interpreted in various social contexts beyond the limits of literature and art. Even though she passed away in 2012, many Korean poets, critics, scholars, and general public still enjoy reading and citing her poems. 